University of Nebraska - Lincoln

DigitalCommons@University of Nebraska - Lincoln

Roman L. Hruska U.S. Meat Animal Research

U.S. Department of Agriculture: Agricultural Center

Research Service, Lincoln, Nebraska

1985

\title{
Mineral Accretion During Prenatal Growth of Cattle
}

\author{
Calvin L. Ferrell \\ U.S. Meat Animal Research Center
}

Dan B. Laster

USDA-ARS

Ronald L. Prior

Hastings, NE

Follow this and additional works at: https://digitalcommons.unl.edu/hruskareports

Part of the Animal Sciences Commons

Ferrell, Calvin L.; Laster, Dan B.; and Prior, Ronald L., "Mineral Accretion During Prenatal Growth of Cattle" (1985). Roman L. Hruska U.S. Meat Animal Research Center. 59.

https://digitalcommons.unl.edu/hruskareports/59

This Article is brought to you for free and open access by the U.S. Department of Agriculture: Agricultural Research Service, Lincoln, Nebraska at DigitalCommons@University of Nebraska - Lincoln. It has been accepted for inclusion in Roman L. Hruska U.S. Meat Animal Research Center by an authorized administrator of DigitalCommons@University of Nebraska - Lincoln. 


\title{
Mineral Accretion During Prenatal Growth of Cattle
}

\author{
Calvin L. Ferrell, Dan B. Laster and Ronald L. Prior
}

\section{Introduction}

Published data on prenatal (fetal) growth in cattle have been limited primarily to birth weights or weights and linear measurements of fetuses at different stages of gestation. Others have provided data describing fetal growth in terms of weight, nitrogen, and energy. These and other data have provided insight into the rates of protein and energy accumulation by the fetus during development and serve as bases for the estimation of protein and energy requirements for fetal development. Objectives of the present study were to describe the patterns of calcium $(\mathrm{Ca})$, phosphorous $(\mathrm{P})$, sodium $(\mathrm{Na})$, potassium $(\mathrm{K})$, magnesium $(\mathrm{Mg})$, iron $(\mathrm{Fe})$, and zinc $(\mathrm{Zn})$ accretion in bovine fetuses and to estimate requirements of these minerals for pregnancy in cattle.

\section{Procedure}

Angus, Hereford, and Red Poll crossbred yearling heifers (732 lb) were mated to five half-sibling Brown Swiss bulls. Heifers ( 81 head) which were diagnosed pregnant at 35 to 42 days postmating were assigned on the bases of weight and breed cross to one of three pens and fed diets that were equal in nitrogen content to achieve maternal weights gains of approximately 0 (low), 1.1 (medium), or 2.2 (high) lb/day. Heifers (three to seven) from each treatment group were slaughtered at about $120,150,180,210,240$, and 255 days postmating at a commercial facility.

Reproductive tracts were recovered at slaughter. Weights of each total gravid (pregnant) uterus, then weights of separate components - fetus, fetal fluids (allantoic and amnionic), uterus, cotyledons, and placenta (fetal membranes with cotyledons removed)-were obtained. Fetal sex was recorded. Fetuses were frozen at $-29^{\circ} \mathrm{F}$ and later ground, mixed, and sampled. Dry matter was determined on duplicate samples by drying in a forced-air oven.

Duplicate samples of each fetus were ashed. Ashed samples were then analyzed for $\mathrm{Ca}, \mathrm{P}, \mathrm{Na}, \mathrm{Mg}, \mathrm{Fe}$, and $\mathrm{Zn}$ content. Data were analyzed by regression analysis.

\section{Results}

Fetal weight and mineral content at different stages of gestation, estimated from regression analyses, are presented in Table 1. $\mathrm{Ca}$ and $\mathrm{P}$ contents of bovine fetuses increased with gestation. Others have observed a more rapid increase of these minerals in fetuses of dairy cows. The $\mathrm{Ca}$ to $\mathrm{P}$ ratio in this study was 1.1 at 100 days of gestation and increased to about 1.6 at 280 days, whereas previous data indicated the $\mathrm{Ca}$ to $\mathrm{P}$ ratio to be about 1.4 at 140 days and about 1.8 near term. The differences between these studies may be attributed largely to differences in the breeds of cattle involved. The results of this study demonstrated that the $\mathrm{Ca}$ to $\mathrm{P}$ ratio was not constant but increased as the fetus developed. These results were a reflection of the different distribution of $\mathrm{Ca}$ and $\mathrm{P}$ in the body as well as the different growth patterns of the different tissues.

Although total fetal $\mathrm{Na}$ and $\mathrm{K}$ contents increased during gestation (Table 1), Na concentration decreased. Others have observed that fetal $\mathrm{Na}$ concentration decreased but that $\mathrm{K}$ concentration increased during gestation.

The $\mathrm{Mg}$ content of bovine fetuses (Table 1) increased 200 fold from 100 days postmating to 280 days. Few data were

${ }^{1}$ Ferrell is a research animal scientist, Nutrition Unit, MARC; Laster is associate deputy administrator, National Program Staff USDA-ARS, Beltsville, Maryland (formerly the research leader, Reproduction Unit, MARC); and Prior is self-employed in Hastings, Nebraska (formerly a research chemist, Nutrition Unit, MARC).

found for comparison with these values. The $\mathrm{Fe}$ content $\mathrm{O}$. bovine fetuses increased 160 fold from 100 to 280 days post. mating. No data were found for comparison with these values $\mathrm{Zn}$ content of bovine fetuses increased 160 fold from 100 tc 280 days of gestation.

Daily rates of fetal weight, $\mathrm{Ca}, \mathrm{P}, \mathrm{Na}, \mathrm{K}, \mathrm{Mg}, \mathrm{Fe}$, and $\mathrm{Zr}$ gains (Table 2) at different stages of gestation were obtainec by differentiation of the relationships between total fetal conten: of these minerals and days of gestation with respect to day o. gestation. The values obtained were considered to be estimates of the rates of accretion of the various fetal components on different days postmating. These values indicated that daily rates of accretion of all fetal components increased during early and mid-gestation, reached a maximum at about 250 days anc then decreased. Previously, we have observed a decline in th $\epsilon$ rate of increase in fetal weight, energy, and nitrogen gain, but did not observe an actual decrease in the rate of fetal growth. The observed decrease may have been due to a breed of sire $x$ breed of dam interaction and to parity of the dam. These data demonstrated that accretion rates in bovine fetuses of al minerals were small during the first two trimesters of gestation but relatively large during the last trimester.

Mineral accretion rates in nonfetal gravid uterine tissues were estimated from the rate of weight change in the uterus, fetal membranes, and fetal fluids at different stages of gestation anc from literature values on the mineral contents of these tissues.

The accretion rates of each mineral in each nonfetal uterine tissue at each stage of gestation were combined with estimates of fetal mineral accretion. Results are presented in Table 3. Comparison of Table 3 to Table 2 reveals that mineral accretion in the nonfetal uterine tissues was small in relation to mineral accretion in the fetal component. Thus, even though errors may be associated with the estimates of non-fetal mineral accretion, these appear to be of little significance in relation to total gravid uterine mineral accretion.

$\mathrm{Ca}$ and $\mathrm{P}$ accretion rates in the gravid uterus (Table 3 ) were lower, especially during the latter stages of gestation, than reported by others. These differences appear to be due largely to the breeds of cattle used in the data base. Previously reported values were derived from estimates of the $\mathrm{Ca}$ and $\mathrm{P}$ contents of the fetuses from dairy cows and from gravid uterine growth curves of Red Danish cattle, both of which resulted in higher values late in gestation than observed in the crossbred fetuses used in this study. Rates of $\mathrm{Na}$ and $\mathrm{K}$ accretion in gravid uterine tissues were slightly lower than estimates obtained previously, but estimates of $\mathrm{Mg}$ accretion rates were much lower in this study. These estimates were based on estimates of the $\mathrm{Mg}$ content of calves at birth. This value is about twofold higher than that observed in the present study. No data were found for comparison with the Fe and $\mathrm{Zn}$ accretion rates observed in this study.

The rates of accretion of the various minerals in the gravid uterus provide estimates of minimal net amounts of the minerals evaluated that need to be available to the uterus for development of the gravid uterine tissues at various stages of gestation in cattle of similar type. Estimates of daily allowances of $\mathrm{Ca}, \mathrm{P}, \mathrm{Na}, \mathrm{K}, \mathrm{Mg}, \mathrm{Fe}$, and $\mathrm{Zn}$ (Table 4) were calculated assuming availabilities of $45,45,100,100,20,50$, and 50 percent, respectively. It should be recognized that availabilities vary depending on mineral source, maturity, physiological state of the animal, etc. Ca availability, for example, may range from about 20 to 100 percent.

The data provide estimates of daily allowances of several minerals for pregnant beef cattle. The allowances obtained should be added to maternal allowances to obtain estimates of total mineral allowances during pregnancy in cattle. 
Table 1.-Weights of various fetal components at various stages of gestationa

\begin{tabular}{lcccccccc}
\hline \multirow{2}{*}{$\begin{array}{l}\text { Jay of } \\
\text { lestation }\end{array}$} & $\begin{array}{c}\text { Weight, } \\
\mathrm{lb}\end{array}$ & $\begin{array}{c}\mathrm{Ca}, \\
\mathrm{g}\end{array}$ & $\begin{array}{c}\mathrm{P}, \\
\mathrm{g}\end{array}$ & $\begin{array}{c}\mathrm{Na}, \\
\mathrm{g}\end{array}$ & $\begin{array}{c}\mathrm{K}, \\
\mathrm{g}\end{array}$ & $\begin{array}{c}\mathrm{Mg}, \\
\mathrm{g}\end{array}$ & $\begin{array}{c}\mathrm{Fe}, \\
\mathrm{g}\end{array}$ & $\begin{array}{c}\mathrm{Zn}, \\
\mathrm{g}\end{array}$ \\
\hline 100 & .77 & 1.11 & 1.00 & .69 & .55 & .054 & .015 & .004 \\
130 & 2.7 & 5.05 & 3.96 & 2.35 & 1.96 & .203 & .056 & .017 \\
160 & 7.8 & 18.3 & 12.9 & 6.62 & 5.71 & .645 & .172 & .057 \\
190 & 18.8 & 53.1 & 34.6 & 15.3 & 13.7 & 1.71 & .442 & .153 \\
220 & 37.7 & 123 & 76.2 & 29.2 & 26.8 & 3.80 & .943 & .331 \\
250 & 63.1 & 227 & 138 & 45.9 & 43.2 & 7.07 & 1.67 & .577 \\
280 & 87.5 & 334 & 205 & 59.3 & 57.1 & 11.0 & 2.46 & .810 \\
\hline
\end{tabular}

$\mathrm{a}_{1 \mathrm{~g}}=.0022 \mathrm{lb}$.

Table 2.-Daily weight gain and mineral gain by the bovine fetus at various stages of gestationa

\begin{tabular}{lccccccrr}
\hline \multirow{2}{*}{$\begin{array}{l}\text { Jay of } \\
\text { jestation }\end{array}$} & $\begin{array}{c}\text { Weight, } \\
\mathrm{g}\end{array}$ & $\begin{array}{c}\mathrm{Ca}, \\
\mathrm{g}\end{array}$ & $\begin{array}{c}\mathrm{P}, \\
\mathrm{g}\end{array}$ & $\begin{array}{c}\mathrm{Na}, \\
\mathrm{g}\end{array}$ & $\begin{array}{c}\mathrm{K}, \\
\mathrm{g}\end{array}$ & $\begin{array}{c}\mathrm{Mg}, \\
\mathrm{mg}\end{array}$ & $\begin{array}{r}\mathrm{Fe}, \\
\mathrm{mg}\end{array}$ & $\begin{array}{r}\mathrm{Zn}, \\
\mathrm{mg}\end{array}$ \\
\hline 100 & 16 & .06 & .05 & .030 & .025 & 3 & 7 & .2 \\
130 & 47 & .24 & .17 & .089 & .076 & 8 & 2.3 & .7 \\
160 & 115 & .72 & .47 & .207 & .185 & 23 & 5.9 & 2.1 \\
190 & 224 & 1.68 & 1.02 & .380 & .352 & 51 & 12.5 & 4.5 \\
220 & 345 & 2.97 & 1.75 & .534 & .515 & 90 & 20.9 & 7.3 \\
250 & 400 & 3.78 & 2.27 & .542 & .545 & 125 & 26.7 & 8.6 \\
280 & 313 & 3.07 & 2.04 & .316 & .343 & 129 & 24.2 & 6.2 \\
\hline
\end{tabular}

$\mathrm{a} 1 \mathrm{~g}=.0022 \mathrm{lb}$.

Table 3.-Daily mineral gain by the bovine uterus at various stages of gestation.

\begin{tabular}{|c|c|c|c|c|c|c|c|}
\hline \multirow[b]{2}{*}{$\begin{array}{l}\text { Day of } \\
\text { gestation }\end{array}$} & \multicolumn{7}{|c|}{ Gravid uterine component ${ }^{\mathrm{a}}$} \\
\hline & $\begin{array}{c}\mathrm{Ca}, \\
\mathrm{g}\end{array}$ & $\begin{array}{l}P_{1} \\
g\end{array}$ & $\begin{array}{c}\mathrm{Na}, \\
g \\
\end{array}$ & $\begin{array}{l}\mathrm{K}, \\
\mathrm{g} \\
\end{array}$ & $\begin{array}{l}\mathrm{Mg}, \\
\mathrm{mg}\end{array}$ & $\begin{array}{l}\mathrm{Fe}, \\
\mathrm{mg}\end{array}$ & $\begin{array}{l}\mathrm{Zn}, \\
\mathrm{mg}\end{array}$ \\
\hline 100 & .07 & .08 & .18 & .08 & 8 & 4.9 & 1.5 \\
\hline 130 & .25 & .21 & .27 & .14 & 15 & 7.4 & 2.3 \\
\hline 160 & .73 & .53 & .41 & .26 & 32 & 12.1 & 3.1 \\
\hline 190 & 1.69 & 1.09 & .61 & .44 & 61 & 19.6 & 6.7 \\
\hline 220 & 2.98 & 1.82 & .76 & .61 & 101 & 28.1 & 9.6 \\
\hline 250 & 3.79 & 2.34 & .76 & .63 & 124 & 32.8 & 10.5 \\
\hline 280 & 3.08 & 2.09 & .48 & .41 & 136 & 28.6 & 7.6 \\
\hline
\end{tabular}

$\mathrm{a}_{1} \mathrm{~g}=.0022 \mathrm{lb}, 1 \mathrm{mg}=.001 \mathrm{~g}$

Table 4.-Estimated daily allowances of various minerals for pregancy in cattlea

\begin{tabular}{llllllll}
$\begin{array}{l}\text { Day of } \\
\text { gestation }\end{array}$ & $\begin{array}{c}\mathrm{Ca}, \\
\mathrm{g}\end{array}$ & $\begin{array}{c}\mathrm{P}, \\
\mathrm{g}\end{array}$ & $\begin{array}{c}\mathrm{Na}, \\
\mathrm{g}\end{array}$ & $\begin{array}{c}\mathrm{K}, \\
\mathrm{g}\end{array}$ & $\begin{array}{c}\mathrm{Mg}, \\
\mathrm{mg}\end{array}$ & $\begin{array}{c}\mathrm{Fe}, \\
\mathrm{mg}\end{array}$ & $\begin{array}{c}\mathrm{Zn}, \\
\mathrm{mg}\end{array}$ \\
\hline 100 & .16 & .18 & .18 & .08 & .04 & 9.8 & 3.0 \\
130 & .56 & .47 & .27 & .14 & .08 & 14.8 & 4.6 \\
160 & 1.62 & 1.18 & .41 & .26 & .16 & 24.2 & 6.2 \\
190 & 3.76 & 2.42 & .61 & .44 & .31 & 39.2 & 13.4 \\
220 & 6.62 & 4.04 & .76 & .61 & .51 & 56.2 & 19.2 \\
250 & 8.42 & 5.20 & .76 & .63 & .62 & 65.4 & 21.0 \\
280 & 6.84 & 4.64 & .48 & .41 & .68 & 57.2 & 15.2 \\
\hline
\end{tabular}

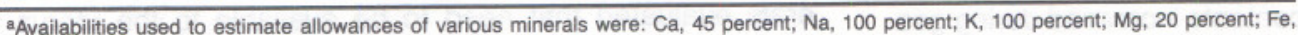
50 percent; $\mathrm{Zn}, 50$ percent. See text for details. 